УДК [339.138+574]/504.03::504.062 \author{
професор кафедри бізнес-адміністрування, маркетингу та менеджменту \\ Zhukov S.A., Doctor of Economics Sciences, Senior Researcher, \\ Associate Professor, Professor of the department of \\ Business Administration, Marketing and Management \\ https://orcid.org/0000-0002-0499-7990
}

\title{
ЕКОЛОГІЧНА ЕВОЛЮЦІЯ МАРКЕТИНГУ
}

\author{
ДВНЗ «Ужгородський національний університет»
}

\begin{abstract}
Дана стаття посвячена дослідженню екологічної еволюції маркетингу, аналізу розвитку та зв'язку між різними етапами - екологічним маркетингом, зеленим маркетингом і сталим маркетингом. Представлене дослідження є науковим пошуком, направленим на встановлення впливу маркетингу на стан навколишнього природного середовища та здоров'я людей, у ході якого запропоновано екологічну еволюцію маркетингу представити у трьох послідовних етапах: екологічний маркетинг; зелений маркетинг; сталий маркетинг. 3 наведених понятійних категорій екологічний маркетинг переважає в дослідженнях українських і вітчизняних науковців, а зелений маркетинг є більш використовуваним поняттям серед науковців в світі.

Перша - екологічна концепція маркетингу характеризується непопулярністю серед підприємств, адже екологізація приводить до додаткових витрат, а відтак і підвищення ціни. Це і пояснює слабку ініціативність та інноваційність у напрямку екологічного менеджменту. Основними проштовхувачами екологічного напрямку на підприємствах виступають інженери та юристи, одні 3 яких удосконалюють виробництво, а інші - пристосовують його до екологічних правових норм і стандартів.

Зелений маркетинг - другий етап - вже торкнувся більшої кількості тих галузей, підприємства яких звертають увагу на вплив своєї діяльності на навколишнє природне середовище завдяки використанню інноваційних і більш екологічних виробництв. Як результат, задовольняються потреби (попит) екологічно орієнтованих споживачів у побутових товарах і послугах.

Третій етап - сталий маркетинг, звичайно, ототожнюється 3 концепцією сталого розвитку, i направлений на задоволення потреб споживачів і забезпечення ринків ресурсами, що компенсують усі витрати, пов'язані з охороною довкілля та формуванням збалансованої соціально-суспільної й екологоекономічної систем.

Для сучасного маркетингу на підприємстві актуальним є концепція побудови трьох складового бізнесу, що враховує крім прибутку, ще й соціальні та екологічні площини функціонування підприємства.

Ключові слова: екологічна еволюиія маркетингу, екологічний маркетинг, зелений маркетинг, сталий маркетинг.
\end{abstract}

\section{ECOLOGICAL EVOLUTION OF MARKETING}

\author{
State University «Uzhhorod National University»
}

This article is devoted to the study of the ecological evolution of marketing, analysis of development and the relationship between the various stages - environmental marketing, green marketing and sustainable marketing. The presented research is a scientific research aimed at establishing the impact of marketing on the environment and human health, during which it is proposed to present the ecological evolution of marketing in three successive stages: environmental marketing; green marketing; sustainable marketing. From the given conceptual categories ecological marketing prevails in researches of the Ukrainian and domestic scientists, and green marketing is more used concept among scientists in the world.

The first - the environmental concept of marketing is characterized by unpopularity among businesses, because greening leads to additional costs and, consequently, higher prices. This explains the weak initiative and innovation in the direction of environmental management. The main pushers of the environmental direction at the enterprises are engineers and lawyers, some of whom improve production, and others - adapt it to environmental legal norms and standards.

Green marketing - the second stage - has already affected more of those industries whose companies pay attention to the impact of their activities on the environment through the use of innovative and more 
environmentally friendly industries. As a result, the needs (demand) of environmentally oriented consumers in household goods and services are met.

The third stage - sustainable marketing, of course, is identified with the concept of sustainable development, and aims to meet consumer needs and provide markets with resources that offset all costs associated with environmental protection and the formation of a balanced socio-social and environmental-economic systems.

For modern marketing at the enterprise the concept of construction of three components of business which considers besides profit, also social and ecological planes of functioning of the enterprise is actual.

Key words: ecological evolution of marketing, ecological marketing, green marketing, sustainable marketing.

Постановка проблеми у загальному вигляді i ïi зв'язок 3 важливими науковими та практичними завданнями. Одним із важливих складових сталого розвитку є підвищення екологізації підприємств на основі концепції соціально-етичного маркетингу та екологічного маркетингу. Однак, практика використання екологічних аспектів, у тому числі і маркетингових підприємствами у різні періоди господарювання була несистемною та мала різну функціональну направленість. Екологічна еволюція маркетингу грунтувалася головним чином на врахуванні екологічних принципів i факторів у діяльності соціально-орієнтованих підприємств. Однак, підприємствам належить прийняти, що органи державної влади також повинні бути включені у вирішення екологічних проблем на регіональному та національному рівнях, а відповідна екологічна політика має бути вбудованою в підприємницький сектор.

Аналіз останніх досліджень, у яких започатковано вирішення проблеми. Аналіз наукових публікацій з екологічного (зеленого) маркетингу показали відірваність від орієнтації на реальні потреби суспільства у питаннях захисту навколишнього природного середовища від негативного впливу виробництв, захисту довкілля та загалом сталого розвитку країн та іï регіонів. Однак, теоретичні питання маркетингу формувалися на основі досвіду розвинутих країн світу без належного пристосування до економічних умов України, а наукові розвідки українських учених 3 екологічного маркетингу переважно носять фрагментований характер щодо аналізу праць зарубіжних учених і практиків. Так, дослідженням проблем екологічного та зеленого маркетингу займались такі вітчизняні та закордонні вчені, як Бородін О.І., Ілляшенко С.М., Катранджиев Х., Кучмійов А.В., Пітті К., Садченко О.В. Всі вони в тій чи іншій мірі зосереджувались на екологічних аспектах маркетингової діяльності, та вплинули розвиток такого важливого питання, як сталого маркетингу. Однак, деякі аспекти ще не належним чином вивчені і потребують деякого уточнення, аналізу та структуризації.

Цілі статті - дослідження науково-практичних підходів до екологічного розвитку маркетингу та застосування його інструментарію в процесі реалізації концепції сталого розвитку на всіх рівнях господарювання.

Виклад основного матеріалу дослідження 3 повним обгрунтуванням отриманих наукових результатів. Для забезпечення сталого розвитку найбільш загрозливими вчені вважають еколого-економічні диспропорції. Більшість регіонів України характеризуються стрімкими темпами зменшення обсягів промислового виробництва, що відчутно відображається на екології та довкіллі. Однак, на сучасному етапі розвитку регіонів, які розглядаються як комплексна система, складовими якої $є$ економічна, соціальна та екологічна підсистеми, саме остання буде найвагомішою конкурентною перевагою [1, с. 21]. Аргументувати це можна завдяки еволюції маркетингових концепцій, остання з яких - концепція соціально-етичного маркетингу найбільше спроможна раціоналізувати взаємодію трьох головних суб'єктів: а) виробників товарів і послуг, кінцева мета яких є отримання прибутку, б) споживачів цих товарів і послуг у формі задоволення потреб, і в) суспільства в цілому, яке прагне до розвитку основних складових життєдіяльності населення: економічного, соціального та екологічного. 
Взаємодія між маркетингом і середовищем людини часто ототожнюється 3 негативним впливом виробничої діяльності людей на їх навколишнє середовище. Існує також інша точка зору на такий взаємозв'язок, коли маркетингова концепція являється запобіжником від реальних і потенційних екологічних лих. Паралельно з еволюцією традиційних маркетингових концепцій, i зокрема в період існування концепції соціально-етичного маркетингу набули популярності і маркетингові субконцепції, що стосуються захисту навколишнього природного середовища, виробництва екологічно чистої продукції, збереження природних ресурсів планети й інших актуальних екологоорієнтовних питань. Саме у цей період (1970-1980рp.) виник напрям екологічного маркетингу (екомаркетінг), або зелений маркетинг (англ. green marketing).

Відмітимо, що зелений маркетинг $є$ популярним поняттям серед наукової спільноти в світі та використовується для відображення маркетингової діяльності, яка направлена на усунення негативних соціальних та екологічних проблем, що виникають внаслідок дії виробництва та розподілу товарів і послуг. На пострадянському науковому просторі поряд із зеленим маркетингом, але частіше застосовується екологічний маркетинг.

Із запропонованих Христо Катранджі чотирьох етапів екологічної еволюції маркетингу - етап зародження; екологічний маркетинг; зелений маркетинг, або маркетинг навколишнього природного середовища; сталий (збалансований) маркетинг [2, с. 72], вважаємо за доцільне використовувати трьох етапну екологічну еволюцію маркетингу - 1) екологічний маркетинг; 2) зелений маркетинг; 3) сталий маркетинг.

Дискусії щодо першого етапу відбувалися ще у 50-60 pp. XX ст., коли Рой Алдерсон проаналізував взаємозв'язок між маркетингом, суспільством і навколишнім середовищем та обгрунтував вплив маркетингової діяльності на навколишнє середовище. Вже у 1970-х роках орієнтація на екологію стала важливою складовою в маркетингу, про що свідчать перші наукові праці про екологічний маркетинг (Карл Хеніон і Томас Кіннер «Екологічний маркетинг»), і саме 3 цього часу наступив період панування екологічного маркетингу. У зазначеній праці авторами надано визначення екологічного маркетингу, згідно з яким цей вид маркетингу охоплює всю маркетингову діяльність, що направлена на усунення наслідків вже існуючих екологічних проблем» [3, c. 75]. Як бачимо, у визначенні простежується досить вузька спрямованість на екологічні проблеми (наприклад, забруднення повітря автомобілями, заводами; нанесення шкоди грунтам через використання хімічних добрив). Більш ширше екологічний маркетинг можна визначити як комплексну та системну маркетингову діяльність (від виробничого маркетингу до збуту) сфокусовану на задоволення екологічних потреб споживачів i запитів суспільства, створення та стимулювання попиту на екологічні товари і послуги, які повинні бути одночасно ефективні економічно та екологічно безпечні при виробництві, споживанні й утилізації, і все це для прибутку та збереження довкілля та здоров'я людей. Американська маркетингова асоціація пропонує такі визначення «екологічного маркетингу»: 1) у споживчому аркетингу - збут товарів, що мають бути безпечними для навколишнього природного середовища; 2) у соціальному маркетингу це процеси від розробки до збуту таких товарів, що мінімізують негативний ефект на природне навколишнє середовище; 3) у маркетингу довкілля - це процеси від виробництва, упакування - до екологічної утилізації товарів [4].

Особливістю цього етапу є те, що екологічну концепцію маркетингу поділяє надто мало підприємств, організацій i споживачів. Головними промоутерами екологічних ідей на підприємствах являються юристи та інженери, які приводять продукцію до екологоправових норм, завдяки покращенню процесів виробництва і як результат - зменшення забруднення (наприклад, встановлення системи каталізаторів вихлопних газів на автомобілі). Все це орієнтовано на майбутні періоди і породжує 
додаткові витрати, що в кінцевому підсумку призводять до підвищення цін. Тому більшість підприємств сприймали екологізацію без явного ентузіазму, хоча були і такі, які стали абсолютними іiі прихильниками, наприклад, компанія Amway. Екологічний маркетинг цього періоду характеризується слабкою ініціативностю та інноваційністю, однак були намагання зменшити частку шкідливих товарів 3 метою вирішення екологічних проблем [4].

Другий етап почався у 1980-ті роки, які відзначилися великими техногенними катастрофами, наприклад, аварія на Чорнобильській AEC (1986р.), аварія танкера компанії Exxon «Эксон Валдиз» у берегів Аляски з розливом 40,9 млн. літрів нафти на 28 тис. км² площі моря (1989 р.) [5], аварія на хімічному заводі Union Carbide, в індійскому місті Бхопал (1984р.). Ці катастрофи показали слабкість людей перед природою, наслідками технологічного розвитку та змусили їх звертати увагу на екологічні проблеми та вирішувати їх спільними зусиллями. У США і Західній Свропі виникає рух і партії «зелених», що популяризує виробництво екологічно чистих продуктів і технологій.

Який же маркетинг був у «зелений» період? Безумовно, зміни торкнулися і його. Так, якщо екологічний маркетинг орієнтувався на такі галузі, як хімічна, нафто- i газодобувна, тобто такі, які явно впливали на екологію, то зелений маркетинг охоплює більше галузей, які більше чи менше дбають про вплив на навколишнє природне середовище. Підприємства розглядаються як системи, що пов'язані з іншими системами - природою, суспільством тощо, і тому зелений маркетинг є систематичним на відміну від екологічного маркетингу. Зелений маркетинг фокусувався на зменшенні шкідливого впливу на навколишнє природне середовище через використання більш сучасних виробничих технологій і нових, інноваційних товарів, що зможуть позитивно вплинути на рівень забруднення довкілля. У свою чергу це забезпечить підприємство конкурентними перевагами завдяки задоволенню попиту споживачів, котрі орієнтуються на екологічно чисту продукцію [4]. Для домогосподарств зелений маркетинг пропонує екологічно чисті засоби для догляду (наприклад, шампунь без сульфатів), чищення (засоби без хлору), екологічно чисті меблі (з натуральної деревини та лаками на водній основі) тощо.

Третій етап екологізації маркетингу асоціюється з концепцією сталого розвитку, про яку вперше доповіла Г.Г. Брундтланд на Міжнародній (Світовій) Комісії з довкілля i розвитку у 1987 р. Функціонерка наголошувала на існуванні тісного взаємозв'язку між соціально-економічним та екологічним розвитком, а тому довкілля і людська діяльність (розвиток) є нероздільними: «Довкілля - це місце нашого життя, а розвиток - це наші дії щодо поліпшення нашого добробуту в ньому», - наголошувала Г.Г. Брундтланд тодішня генеральний секретар ООН. Згідно ії звіту-доповіді «Наше спільне майбутнє» термін «сталий розвиток» визначається як «такий тип розвитку, при якому потреби нинішнього покоління задовольняються, але не за рахунок задоволення потреб майбутніх поколінь» [6]. Головною ідеєю цитати є виважене використання природних ресурсів, швидкість споживання яких дорівнює швидкості їх відновлення (самою природою, чи людьми). Заснована на комплексному, системному та інтегрованому підходах щодо вирішення економічних, соціальних та екологічних проблем людства, концепція сталого розвитку є популярною у світі, i вона присутня в програмах $\mathrm{i}$ стратегіях розвитку на всіх рівнях господарювання.

3 2000-х років зелений маркетинг трансформується в маркетинг для сталого розвитку, або сталий маркетинг. Як зазначав Кен Пітті, вперше сталий маркетинг визначив Фуллер у 2000 р. як планування, реалізацію та контроль створення, встановлення ціни та розподілу продуктів у певній послідовності етапів 3 дотриманням критеріальності: задоволення потреб споживачів, досягнення цілей підприємства, 
гармонії з екосистемою. Згодом з'являються публікації інших авторів, і були сформовані принципи сталого (збалансованого) маркетингу: орієнтація на майбутні потреби поколінь, а не на потреби сьогодення; справедливість розподілу продукції та соціальноекономічний порядок; ядром $є$ потреби, а не бажання споживачів, адже більшість людей мають можливість зробити собі запаси товарів першої необхідності (вода, харчі, одяг...), тобто задовольнити основні потреби [7, с. 140-141]. Отже, сталий маркетинг переважно орієнтований на задоволення потреб споживачів, тобто він функціонує в межах споживчого маркетингу. Сталий маркетинг радикально підходить до дослідження та задоволення ринків, постійно шукаючи ресурси або шляхи покриття виробничих i споживчих витрат, що відносяться до системи охорони навколишнього природного середовища, для створення сталої та збалансованої економічної системи. Крім екологічних проблем сталий маркетинг дбає і про соціально-суспільні аспекти життєдіяльності людей і господарювання [4].

Зазначимо, що починаючи з екологічного маркетингу і до сталого маркетингу вони почали своє функціонування в контексті концепції соціально-етичного маркетингу. Враховуючи характеристики етапів екологічної еволюції маркетингу виділяють наступні передумови їх створення та функціонування:

- маркетингові - знижували негативний вплив маркетингу на суспільство;

- екологічні - як наслідок антропогенної діяльності людини при техногенному впливі та забрудненні навколишнього природного середовища;

- соціальні, коли наслідком забруднення навколишнього природного середовища стало погіршення здоров'я людей, що зумовило нову потребу в безпечній для організму екологічній продукції, і як наслідок орієнтацію бізнесу на екологізацію;

- технологічно-інноваційні - розвиток технологій та інноваційних способів виробництва, інноваційних управлінських рішень, тобто всього того, що зумовлюють виробництво екологічної продукції та зниження навантаження на довкілля;

- економічні - створення економічного підгрунтя для підвищення ефективності виробництва екологічної та безпечної продукції [4].

На всіх рівнях господарювання важливим $є$ формування екологічних ініціатив, $\mathrm{i}$ на цій основі розроблення відповідних концепцій екологічного виробництва товарів, їх споживання, переробки та утилізації відходів. Це вимагає удосконалення інструментів комплексу маркетингу у відповідності з екологічним фактором.

Виділяють п'ять орієнтирів екологізації маркетингу:

1) нормативний - врахування норм та обмежень щодо екології при продуктовому маркетингу;

2) орієнтований на екологічні потреби населення, що виникли через незадовільний стан довкілля та формування екологічної філософії мислення у суспільстві;

3) природничо-ресурсний - суб'єктами якого є органи державної, регіональної та місцевої влади, в розпорядженні яких є природні ресурси;

4) некомерційний, що направлений на охорону довкілля, підвищення якості життя людей, відтворення природного середовища;

5) орієнтований на отримання знань щодо екології [8, с. 56-57].

Враховуючи вище викладене, зазначимо, що сучасний маркетинг на підприємстві окрім отримання прибутку повинен зосереджуватися на двох інших цінностях - людях і довкіллі, тобто того, що забезпечить життєдіяльність наступних поколінь. В цьому контексті для підприємств актуальним є триєдність - triple bottom line (TBL aбo 3BL) концепція побудови бізнесу, відповідно до якої власники та менеджери вимушені враховувати крім фінансових показників (прибутку) і соціальні (суспільство) та екологічні (довкілля) аспекти функціонування підприємства. При концепції TBL 
ставлення до фінансових центрів усіх рівнів зміниться при ситуації, коли соціальні й екологічні питання впливатимуть на прибутковість.

Відносно етичної орієнтації споживачів варто навести деякі дані Європейської комісії з корпоративної соціальної відповідальності. Так, у Великобританії кількість таких споживачів зросла за 6 років з 10\% до 32\%, у Франції - до 22\%. Екологічні принципи та стандарти переважно втілюють великі підприємства для підтримання та покращення власного іміджу, основою якого є стійкість прийнятої стратегії та сталий маркетинг, як забезпечувальні фактори підвищення конкурентоспроможності [9]. Підприємства провідних країн світу вдало реалізовують сталий маркетинг. Натомість в Україні майже в кожній прийнятій стратегії розвитку регіону, або країни в цілому є в певній мірі згадування про «сталість» і маркетинг, однак відсутній контроль за виконанням таких програм і стратегій. Однак, вітається таке намагання органів державної, регіональної та місцевої влади через програмно-стратегічні документи вплинути на екологічну ситуацію, до того ж рекомендувати якості інструменту маркетинг.

Гірше складається ситуація в підприємницькому середовищі. Аргументувати таку позицію можна дуже простими прикладами і фактами: смок у металургійних містах (Кривий Ріг, Маріуполь...); молоко, що не скисне протягом декількох днів; концентровані 100\% натуральні або без ГМО продукти; м'ясо, що зменшується вдвічі при його смаженні; пестициди в овочах і фруктах; неефективні ліки без відповідного вмісту тощо.

Висновки. При дослідженні екологічної еволюції маркетингу запропоновано виділяти три іiі стадії: екологічного маркетингу, зеленого маркетингу та сталого маркетингу. Якщо на початку екологічного маркетингу з'являлися точкові аналітичні праці щодо встановлення зв'язків між маркетингом, суспільством і довкіллям, то в подальшому спостерігаються практичні дії зі зменшення наслідків шкідливого виробництва та не зовсім соціально-орієнтованого маркетингу, а в наукових працях переважає термін екологічний маркетинг.

Етап зеленого маркетингу орієнтований на ті галузі, які найбільш згубно впливають на екологію та довкілля. Все більше з'являються підприємства, що чітко позиціонуються як затяті прихильники «зелених» ідей, з'являються відповідні громадські рухи і партії і все це на фоні екологічних і техногенний катастроф кінця XX ст. Змінюється також і маркетингова думка та з'являються концептуально нові «зелені» товари, систематизується управління маркетинговою діяльністю з чіткою орієнтацією на збереження довкілля для наступних поколінь і врахуванням потреб суспільства.

Третій етап екологізації маркетингу трансформується в концепцію сталого маркетингу, що характеризується чіткою, навіть фанатичною орієнтацією на майбутню перспективу, соціальну справедливість та еколого-економічні потреби населення. Останні проблеми $є$ найвідчутнішими і загрозливими для реалізації сталого розвитку, через це у систему на різних рівнях управління сталим розвитком інтегруються природоохоронні цілі, адаптується система оцінювання процесів відтворювання 3 урахуванням прийнятих міжнародних екологічних вимог і стандартів, у тому числі i щодо шкідливих викидів, утворення відходів, змінюється політика витрат, які повинні розглядатися як загальносуспільні, що є неминучим у сучасному світі.

Отже, є надія, що вітчизняні підприємства як увесь цивілізований бізнес у світі активізують свою екологічно та соціально орієнтовану діяльність, і почнуть у своїх стратегіях використовувати принципи сталого розвитку та концепцію сталого маркетингу. До того ж, враховуючи, що сталий маркетинг доволі рідко досліджується вітчизняними науковцями, на відміну від екологічного або зеленого маркетингу, тому вважаємо за потрібне в подальшому досліджувати дану тематику. 


\section{Список бібліографічного опису}

1. Похилько С.В. Сучасні еколого-економічні аспекти регіонального підходу в управлінні природокористуванням. Вісник Сумського державного університету. Серія: Економіка. 2014. №3. С. 18-26. URL: http://nbuv.gov.ua/UJRN/VSU_ekon_2014_3_4.

2. Katrandjiev H. Ecological, Green and Sustainable Marketing: Synonyms or an Evolution of Ideas? Economic Alternatives, №1: Sofia. 2016. P. 71-82. URL: https://www.unwe.bg/uploads/Alternatives/Katrandjiev_br1_2016-7.pdf.

3. Fisk G. Criteria for a Theory of Responsible Consumption, Journal of Marketing, Vol. 37, №. 2, 1973. P. 24-31.

4. Екологічний маркетинг. Вікіпедія. Вільна енциклопедія. https://uk.wikipedia.org/wiki/\%D0\%95\%D0\%BA\%D0\%BE\%D0\%BB\%D0\%BE\%D0\%B3\%D1\%96\%D1\%87\%D0\%BD\%D 0\%B8\%D0\%B9_\%D0\%BC\%D0\%B0\%D1\%80\%D0\%BA\%D0\%B5\%D1\%82\%D0\%B8\%D0\%BD\%D0\%B3.

5. Выброс нефти из танкера «Эксон Валдиз». Википедия. Свободная энциклопедия. URL: https://ru.wikipedia.org/wiki/\%D0\%92\%D1\%8B\%D0\%B1\%D1\%80\%D0\%BE\%D1\%81_\%D0\%BD\%D0\%B5\%D1\%84\%D $1 \% 82 \% \mathrm{D} 0 \% \mathrm{~B} 8 \% \mathrm{D} 0 \% \mathrm{~B} 8 \% \mathrm{D} 0 \% \mathrm{~B} 7 \% \mathrm{D} 1 \% 82 \% \mathrm{D} 0 \% \mathrm{~B} 0 \% \mathrm{D} 0 \% \mathrm{BD} \% \mathrm{D} 0 \% \mathrm{BA} \% \mathrm{D} 0 \% \mathrm{~B} 5 \% \mathrm{D} 1 \% 80 \% \mathrm{D} 0 \% \mathrm{~B} 0 \% \mathrm{C} 2 \% \mathrm{AB} \% \mathrm{D}$ 0\%AD\%D0\%BA\%D1\%81\%D0\%BE\%D0\%BD_\%D0\%92\%D0\%B0\%D0\%BB\%D0\%B4\%D0\%B8\%D0\%B7\%C2\%BB.

6. Комісія Брунтланд. Вікіпедія. Вільна енциклопедія. https://uk.wikipedia.org/wiki/\%D0\%9A\%D0\%BE\%D0\%BC\%D1\%96\%D1\%81\%D1\%96\%D1\%8F_\%D0\%91\%D1\%80\%D1 $\% 83 \% \mathrm{D} 0 \% \mathrm{BD} \% \mathrm{D} 0 \% \mathrm{~B} 4 \% \mathrm{D} 1 \% 82 \% \mathrm{D} 0 \% \mathrm{BB} \% \mathrm{D} 0 \% \mathrm{~B} 0 \% \mathrm{D} 0 \% \mathrm{BD} \% \mathrm{D} 0 \% \mathrm{~B} 4$.

7. Peattie K. Towards Sustainability: The Third Age of Green Marketing, The Marketing Review, 2, 2001. P. 129-146. URL: https://www.researchgate.net/publication/233619700_Towards_Sustainability_The_Third_Age_of_Green_Marketing.

8. Садченко Е.В., Харичков С.К. Экологический маркетинг: понятия, теория, практика и перспективы. Одесса, Инст. проблем рынка и эк.-экол. исслед. НАН Украины, 2001. 146 с.

9. Сталий маркетинг - модна тема чи інший підхід до ведення бізнесу? Менеджмент@БЛОГ. Блог авторів порталу Management.com.ua. 2010. URL: http://www.management.com.ua/blog/1107.

\section{References}

1. Pokhyl'ko S.V. Suchasni ekoloho-ekonomichni aspekty rehional'noho pidkhodu v upravlinni pryrodokorystuvannyam. Visnyk Sums'koho derzhavnoho universytetu. Seriya: Ekonomika. 2014. №3. S. 18-26. URL: http://nbuv.gov.ua/UJRN/VSU_ekon_2014_3_4. [in Ukrainian].

2. Katrandjiev H. Ecological, Green and Sustainable Marketing: Synonyms or an Evolution of Ideas? Economic Alternatives, №1: Sofia. 2016. P. 71-82. URL: https://www.unwe.bg/uploads/Alternatives/Katrandjiev_br1_2016-7.pdf.

3. Fisk G. Criteria for a Theory of Responsible Consumption, Journal of Marketing, Vol. 37, №. 2, 1973. P. 24-31. URL: https://www.jstor.org/stable/1250047?seq=1.

4. Ekolohichnyy marketynh. Vikipediya. Vil'na URL: https://uk.wikipedia.org/wiki/\%D0\%95\%D0\%BA\%D0\%BE\%D0\%BB\%D0\%BE\%D0\%B3\%D1\%96\%D1\%87\%D0\%BD\%D 0\%B8\%D0\%B9_\%D0\%BC\%D0\%B0\%D1\%80\%D0\%BA\%D0\%B5\%D1\%82\%D0\%B8\%D0\%BD\%D0\%B3. [in Ukrainian]. 5. Vyibros nefti iz tankera «Ekson Valdiz». Vikipediya. Svobodnaya entsiklopediya. URL: https://ru.wikipedia.org/wiki/\%D0\%92\%D1\%8B\%D0\%B1\%D1\%80\%D0\%BE\%D1\%81_\%D0\%BD\%D0\%B5\%D1\%84\%D $1 \% 82 \% \mathrm{D} 0 \% \mathrm{~B} 8$ \%D0\%B8\%D0\%B7_\%D1\%82\%D0\%B0\%D0\%BD\%D0\%BA\%D0\%B5\%D1\%80\%D0\%B0_\%C2\%AB\%D 0\%AD\%D0\%BA\%D1\%81\%D0\%BE\%D0\%BD_\%D0\%92\%D0\%B0\%D0\%BB\%D0\%B4\%D0\%B8\%D0\%B7\%C2\%BB. [In Russian].

6. Komisiya Bruntland. Vikipediya. Vil'na URL: https://uk.wikipedia.org/wiki/\%D0\%9A\%D0\%BE\%D0\%BC\%D1\%96\%D1\%81\%D1\%96\%D1\%8F_\%D0\%91\%D1\%80\%D1 $\% 83 \% \mathrm{D} 0 \% \mathrm{BD} \% \mathrm{D} 0 \% \mathrm{~B} 4 \% \mathrm{D} 1 \% 82 \% \mathrm{D} 0 \% \mathrm{BB} \% \mathrm{D} 0 \% \mathrm{~B} 0 \% \mathrm{D} 0 \% \mathrm{BD} \% \mathrm{D} 0 \% \mathrm{~B} 4$. [in Ukrainian].

7. Peattie K. Towards Sustainability: The Third Age of Green Marketing, The Marketing Review, 2, 2001. P. 129-146. URL: https://www.researchgate.net/publication/233619700_Towards_Sustainability_The_Third_Age_of_Green_Marketing.

8. Sadchenko E.V., Harichkov S.K. Ekologicheskiy marketing: ponyatiya, teoriya, praktika i perspektivyi. Odessa, Inst. problem ryinka i ek.-ekol. issled. NAN Ukrainyi, 2001. $146 \mathrm{~s}$.

9. Stalyy marketynh - modna tema chy inshyy pidkhid do vedennya biznesu? Menedzhment@BLOH. Bloh avtoriv portal. Management.com.ua. 2010. URL: http://www.management.com.ua/blog/1107. [in Ukrainian].

Дата подання публікації 25.08.2020 p. 